\title{
Tourism and Its Impact on the Local Economy of Nagarkot $^{1}$
}

- Sumita Rai

rightorock@gmail.com

Nagarkot is a popular holiday destination $32 \mathrm{~km}$ north-east from the capital city, Kathmandu. It is situated at the altitude of 7, 200 feet. The place is known specifically for its dawn time, for a beautiful view of sunrise over the Eastern Himalayas. The best time to visit Nagarkot would be between October and March. Monsoon clouds obstruct wonderful views between June and September. Nagarkot is very much a resort village, where people come to escape the sweltering heat of the city and stay overnight. Very few visitors stay longer.

This article, using field-notes, briefly describes the status of tourism at Nagarkot. The study takes the case of four major aspects of tourism industry - accommodations, restaurants, tourists and outlets - to examine the impact of tourism in the local economy.

\section{Accommodations}

Out of the 32 establishments covered in the study, 52\% were registered as hotels, $46 \%$ as resorts and $2 \%$ as lodges. The overall capacity of all the establishments is 603 rooms and 1288 beds. Of all the rooms, $74 \%$ are twin bedrooms. Similarly, $44 \%$ of the total establishments are VAT registered, and 56\% PAN registered.

The period between Ashwin and Poush (September-December) is identified as peak time for the inflow of tourists. The

\footnotetext{
${ }^{1}$ Research funded by NTB. Detailed Report is available with the author and is a part of the Independent Study Undertaken for the Master in Development Studies, School of Arts , Kathmandu University, 2012
} 
remaining months, known mainly as the slack period in business, compel $72 \%$ of the total establishments to decrease their room tariff rates. Some $44 \%$ tourists prefer to stay a couple of nights, $35 \%$ to stay overnight and the rest $(22 \%)$ for more than 3 nights.

The average expenditure of an individual tourist per stay is Rs.7505. The 32 establishments employed 453 staff members, of which $88 \%$ are males and $12 \%$ females. On average, females are paid $2.9 \%$ less than their male co-workers. Regarding the peripheral distribution of employees, $59 \%$ are local (periphery 1) people, $8 \%$ hail from the city of Bhaktapur (periphery 2 ) and the remaining $33 \%$ from outside Bhaktapur (periphery 3 ).

During the peak months $40 \%$ of total expenditure on purchase of food items is spent in periphery $3,45 \%$ in periphery 2 and $15 \%$ in periphery 1 . For slack months the share of purchase is $35 \%, 51 \%$ and $14 \%$ for periphery 1,2 and 3 , respectively. The mean for total annual expenses on purchase of non-food items is Rs.1,011,088. Some 19\% of the establishments have acquired loan. While $56 \%$ of the total establishments claim to have experienced increase in the number of visitors within last five years, $38 \%$ of them report of a positive impact in their business because of Tourism Year 2011. Of the total recommendations for improvement of tourism flow in Nagarkot, $27 \%$ emphasized on proper management and improvement of infrastructure.

\section{Restaurants}

Of all the restaurants in Nagarkot, $73 \%$ are registered as restaurants and the rest $27 \%$ as cafés. Majority (73\%) of such establishments are family businesses. The restaurant business is seen to have been in operation for 11 years in average. Also, the average number of tables in restaurants/cafes in Nagarkot is 7.5 and seating capacity 31 . 
Ashwin, Kartik and Mangsir (September-November) are peak months for restaurant business in Nagarkot. Baisakh (AprilMay), Poush (December-January) and Magh (JanuaryFebruary) are moderate months. Jestha (May-June), Asadh (June-July), Shrawan (July-August), Bhadra (AugustSeptember), Falgun (February-March) and Chaitra (MarchApril) are slack months. The average tourist arrival for peak months is 673 , and 200 for slack months. The slack months experience the average seasonal drop of $54 \%$ in total arrivals.

Dinner, drinks and snacks are the most popular meals served to tourists. The average amount of sales of food items per day in peak season is Rs.5955. In slack season, the amount dwindles to Rs.2173 per day. In the same way, the individual tourist's average expenditure per visit to restaurants/cafes is Rs.368. Majority (46\%) of the establishments have experienced the number of tourists rising in the last five years, $36 \%$ seen the arrivals going down, and 9\% felt no change in the arrival patterns.

The Tourism Year 2011 appears to have made a mixed impact on the overall tourism industry of Nagarkot. While $45 \%$ of the total establishments report positive impact, $45 \%$ insist on a nochange situation, and $10 \%$ claim to have experienced negative impact. Similarly, $18 \%$ of the establishments report the increase in sale of food items, the majority (73\%) say it has decreased, and only $9 \%$ see no change in sales from the previous year.

The restaurants have 54\% of their total staff from periphery 1 , and $46 \%$ from periphery 3 . The average number of permanent male staff in restaurants is 3 , while that of female staff is 1.6. The average of the total permanent employees is 4.5. And, the average monthly salary for permanent male staff amounts to Rs.5072. This is slightly higher than that of the permanent female staff, which is Rs.4591. The average salary for permanent staff is Rs. 4832 . 
The establishments purchase $28 \%$ of the food items from periphery $1,53 \%$ from periphery 2 and $35 \%$ from periphery 3 in peak season. In slack season $36 \%$ of the food is purchased from periphery $1,58 \%$ from periphery 2 and $6 \%$ from periphery 3 . The average tourism-related expenditure amounts to Rs. 31318, while Rs. 12545 goes for donation and Rs.10409 to other miscellaneous headings. Similarly, only $18 \%$ of the total establishments have taken loans. A high majority of the restaurateurs $(91 \%)$ suggest improvement in tourist arrivals in Nagarkot. They recommend the addition in recreational activities as the main requirement in this direction.

\section{Tourists}

Of the visitors surveyed, $13 \%$ hail from the SAARC region, $27 \%$ from China and the rest of Asia, 47\% from Europe and the remaining 13\% from other countries. Shrawan (July-August) is the preferred month of $47 \%$ tourists. It is seen that $60 \%$ tourists travel through privately arranged trips, and $40 \%$ through travel agencies. While $40 \%$ of the tourists are travelling alone, $60 \%$ are in groups. Only $13 \%$ tourists stay more than two nights, while $20 \%$ spend two nights and the remaining majority $(47 \%)$ prefer a single night.

The responses from 15 tourists reveal that the average accommodation rate per night per person is Rs.670. The rate per night per room comes to Rs.1107. Similarly, the average expense of per visitor on food per day is Rs.542, and on transportation Rs. 330. All of the respondents have been found satisfied with the local people's hospitality. They say that security arrangement is satisfactory and encouraging. Of the total 15 respondents, only $16 \%$ expressed willingness to contribute an average of Rs.100 to improve the environment in Nagarkot.

\section{Outlets}

This research covered- 6 outlets, almost a census for the outlets targeting tourists. The major items sold by $67 \%$ outlets were 
snacks and drinks and 33\% sold wooden statues. Ashwin and Kartik (September-November) were peak months for business in the outlets. In the same way, the he average number of visitors for peak season is 36 and in slack season 14 . The mean total peak season sales amount to Rs.61667, and for slack season it is Rs.9667. The average expenditure per tourist per visit to outlets reaches Rs.1033.

All $(100 \%)$ of the outlets are family-run businesses. The establishments have employed $64 \%$ males and $36 \%$ females. Of which, $13 \%$ are locals, $13 \%$ from Bhaktapur and the rest (74\%) from outside Bhaktapur. According to $67 \%$ of the outlet owners, Tourism Year 2011 has had positive impacts on their business. However, $17 \%$ of them complain of a loss in business, and the rest $(16 \%)$ report to have experienced no change in sales. Regarding the increase in tourist arrivals in the days ahead, majority of respondents $(61 \%)$ suggest improvement in management of infrastructures, and addition in activities and basic facilities.

\section{Conclusion}

Majority of respondents indicate an optimistic picture in that the number of visitors is increasing and the hospitality sector is expending steadily. However, to retain the growth and to prolong the stay of the tourists, Nagarkot should focus on improving infrastructure, especially road and water supply and add innovative recreational activities.

Tourism in Nagarkot is a very important economic activity. It is impacting local economy in terms of income and employment generation not only directly but indirectly as well- especially local milk, meat and vegetable vendors. However, much needs to be done to enhance attractions in Nagarkot to increase tourist arrivals which will in turn augment local economy namely revenue and service sector. 